Canadian University Music Review

Revue de musique des universités canadiennes

\title{
Interpretation out of Contradiction: A World of Music in the West Indies
}

\section{Jocelyne Guilbault}

\section{Numéro 14, 1994}

URI : https://id.erudit.org/iderudit/1014308ar

DOI : https://doi.org/10.7202/1014308ar

Aller au sommaire du numéro

\section{Éditeur(s)}

Canadian University Music Society / Société de musique des universités canadiennes

\section{ISSN}

0710-0353 (imprimé)

2291-2436 (numérique)

\section{Découvrir la revue}

\section{Citer cet article}

Guilbault, J. (1994). Interpretation out of Contradiction: A World of Music in the West Indies. Canadian University Music Review / Revue de musique des universités canadiennes, (14), 1-17. https://doi.org/10.7202/1014308ar

\section{Résumé de l'article}

This paper addresses the researcher's double challenge: to acknowledge and situate contrasting experiences of the same phenomenon and yet to integrate them into a personal rendition of that phenomenon. An examination of the various strategies employed in ethnographic writing, from the copious use of quotations to dialogical or polyphonic writing, shows how contradictory viewpoints have been given more attention in ethnographic literature, as the politics of representation have developed into an important debate in the social sciences. While these various approaches have undeniably allowed more voices to be heard, they have nevertheless left unanswered the problem of interpretation in the case of contested appropriations or contradictory versions of the same phenomenon. The simple fact of integrating various voices in an ethnography does not indeed constitute in an by itself an explanation of what is being said and why.

This paper examines possible uses and treatments of diverging voices in ethnographic writing. By way of illustration, I emphasize the great complexity of the responses and interpretations generated by zouk, a mass-distributed popular music from the West Indies, by presenting contrasting voices and viewpoints from the islands of Guadeloupe, Martinique, Domenica, and Haiti. By doing so, I show, on the one hand, how each viewpoint can provide distinct types of knowledge. On the other hand, I argue that while there can be no analysis which can provide final answers to the questions raised by controversial phenomenon such as zouk, not all the points of view should be accorded the same importance.
All Rights Reserved @ Canadian University Music Society / Société de musique des universités canadiennes, 1994
Ce document est protégé par la loi sur le droit d'auteur. L’utilisation des services d'Érudit (y compris la reproduction) est assujettie à sa politique d'utilisation que vous pouvez consulter en ligne.

https://apropos.erudit.org/fr/usagers/politique-dutilisation/ 


\title{
INTERPRETATION OUT OF CONTRADICTION: A WORLD MUSIC IN THE WEST INDIES*
}

\author{
Jocelyne Guilbault
}

\section{Ethnographic Interpretation and the Study of Popular Music}

Ethnomusicological works have customarily focused on single musical events, on several musical phenomena from the same community, or have compared various musical cultures to find a common denominator. But rarely have they been concerned with understanding how different cultures respond to the same music. More recently in the discipline, the study of mass-distributed popular music has brought into focus the formidable challenge of interpreting the reception and appropriation of the same phenomenon in several cultures. How does one interpret the success or unpopularity of a musical genre in milieus that are shaped by profoundly different social, cultural, political, and economic experiences? In this paper I want to argue that the task remains complex, but perhaps no more so than trying to understand the contradictory responses to the same phenomenon within one population: the factors and mediations that influence musical choices and help nurture a sense of self-identification for individuals living in different countries are dramatized - and therefore, in many ways, made more obvious - by referring to contrasting national, cultural, political, and economic histories. The advantage of studying a music from the point of view of five distinct populations is that not only can one describe the relative importance and meanings the same music assumes in different contexts, but also one can identify some of the most significant influences on the perception and evaluation of a popular music in a particular region - a point to which I will return. Yet the initial question remains: how does one deal with contradictory responses in ethnographic writing?

There have been several very well-documented attempts in the social sciences

\footnotetext{
* This study was made possible thanks to the financial support of the Social Sciences and Humanities Research Council of Canada, which I gratefully acknowledge here. This paper, presented at the thirty-seventh annual meeting of the Society for Ethnomusicology at Seattle, Washington, October 1992, is a condensed and revised version of the main arguments presented in two chapters of (Part II) Zouk: World Music in the West Indies (Chicago: University of Chicago Press, 1993).
} 
to give a voice to diverging opinions. ${ }^{1}$ These strategies include the discursive mode, which "tend[s] to be concerned with the representation of research contexts and situations of interlocution;" 2 the dialogical mode, where the ethnography is presented in the form of a dialogue between two individuals who "actively negotiate a shared vision of reality;" 3 and the polyphonic text, which is made up of several "authors" (indigenous and non-indigenous) in an ideally shared position of ethnographic authority, which James Clifford characterizes as a "utopia of plural authorship that accords to collaborators textual strategy, not merely the status of independent enunciators, but that of writers." ${ }^{4}$ As Clifford indicates after reviewing the attempts, new forms of writing and new textual experiments open up new possibilities in the representation of the Other - but guarantee none. In recent critical thought, the focus on the structures and contours of various modes of writing in the social sciences and, in particular, in anthropology, has led to the elimination or underplaying of the ethnographer's intentions and decisions ${ }^{5}$ at the risk of seemingly concealing an agenda of pluralism. ${ }^{6}$ Moreover, although these approaches have undeniably allowed more voices to be heard, they have left unanswered the problem of interpretation in contested appropriations or contradictory versions of the same phenomenon. The simple fact of integrating voices in an ethnography does not constitute in and

1 For a very useful survey of experimental ethnographies, see James Clifford, The Predicament of Culture: Twentieth-Century Ethnography, Literature, and Art (Cambridge: Harvard University Press, 1988); James Clifford and George E. Marcus, eds., Writing Culture: The Poetics and Politics of Ethnography (Berkeley: University of California Press, 1986); Johannes Fabian, Time and the Other: How Anthropology Makes Its Object (New York: Columbia University Press, 1983); Hussein Fahim, ed., Indigenous Anthropology in Non-Western Countries (Durham: University of North Carolina Press, 1982); George E. Marcus and Dick Cushman, "Ethnographies as Texts," Annual Review of Anthropology 11 (1982): 25-69; and George E. Marcus and Michael M.J. Fisher, Anthropology as Cultural Critique: An Experimental Moment in the Human Sciences (Chicago: University of Chicago Press, 1986).

2 Clifford, The Predicament of Culture, 42.

3 Ibid., 43.

$4 \mathrm{Ibid} ., 51$. This last type of ethnographic writing has seldom been attempted, but there are notable examples. See, for instance, Donald M. Bahr et al., Piam Shamanism and Staying Sickness (Tucson: University of Arizona Press, 1974); Ian Majnep and Ralph Bulmer, Birds of My Kalam Country (Auckland: Oxford University Press, 1977); James Walker, Lakota Belief and Ritual, edited by Raymond J. DeMallie (Lincoln: University of Nebraska Press, 1982); and Richard Price, First-Time: The Historical Vision of an Afro-American People (Baltimore: Johns Hopkins University Press, 1983).

5 Paul Rabinow, "Representations Are Social Facts: Modernity and Post-Modernity in Anthropology," in Writing Culture: The Poetics and Politics of Ethnography, ed. James Clifford and George E. Marcers, 247.

6 As Raymond Rocco explains in "The Theoretical Construction of the 'Other' in Postmodernist Thought: Latinos in the New Urban Political Economy," Cultural Studies 4, no. 3 (1990): 32130 , pluralism is the expression of stability, the absence of conflict, which in reality only points to the ability of the dominant system to mediate difference. 
by itself an explanation of what is being said and why. The question is how can various voices be made manifest and given authorial presence at the same time as ethnographers make it clear how these voices are integrated into a personal rendition in ethnographic writing?

\section{The Study of a World Music in Five Islands}

Over the past five years, I have studied the reception and appropriation of the world music zouk in the five Caribbean Creole-speaking countries, Martinique, Guadeloupe, Dominica, St. Lucia, and Haiti. Zouk's recognized status as a world music has been an important factor in my study.

The use of the term "world music" in ethnomusicology is not new. What is new, however, is the way this term has been appropriated in the 1980s, initially by eleven independent record companies in Britain and then by multinational labels in campaigns to promote non-Anglo-American pop music artists. The idea was that by using this label in record stores, "the public would have an accessible section where they could find the records of [these] artists." Technically, the term "world music" (known as "world beat" music in North America) is a label with such ambiguous references that a typology of the various kinds of music it groups together would be necessary in order to understand its multifaceted meanings. Even then, however, no consensus would be reached: depending upon the country, distributors, record-shop owners, and music journalists, the social, political, or demographic position of certain minority groups in a given country, the category of "world music" would vary in content and include various sets of musical genres. ${ }^{8}$ Vis-à-vis zouk, however, I am referring only to what could be regarded as a subset of world music, that is, popular musics that have emerged in the 1980s; that are mass-distributed worldwide yet associated with minority groups and small or industrially developing countries; that combine local musical characteristics with those of mainstream genres in today's transnational music-related industry $;{ }^{9}$ and that have reached the markets of industrialized countries. ${ }^{10}$

7 Stan Rijven, "Introduction," Popular Music 8, no. 3 (1989): 216.

8 It is interesting to note, for example, that in the United States, where there is an important Latino population, salsa is usually not considered world music (because it is no longer perceived as foreign), whereas in Britain, with a considerably smaller Latino population, the same genre is included.

9 The musical characteristics of mainstream genres that are commonly integrated with musical languages and instruments of non-Western origin typically include the use of instruments such as the electric bass and guitar, as well as synthesizers, along with the adoption of harmonic progressions based on Western classical tonal musical language.

10 Rijven, "World Music," Popjaarboek 88/89 (1988): 65-70, and Rijven, "Introduction," 215-19. 
As a world music, zouk has received special attention from Creole-speakers in the Caribbean. On the one hand, it can surely be assumed that a local music's exportability and considerable commercial value would give rise to exceptional pride among the local populations. For that reason and also because it is publicly recognized that, like many world musics, zouk is a mix of musical influences, it has become a contested terrain: more than one local cultural group has claimed it as its own invention. On the other hand, to a much greater extent than any other imported music - to which small populations are customarily exposed - zouk, precisely because of its worldwide recognition and commercial value, has increased its influence on the local scenes exponentially. ${ }^{11}$ From these two perspectives, I have been particularly interested in zouk because its manifest contribution to many local changes and its assumed role of representing Creole music abroad has made it one of the most controversial topics of discussion back home in the Creole-speaking islands.

Zouk elicits both a ferocious hate and unconditional love. In the context of my study, this dichotomy posed serious problems in relation to the definition I could offer of the music. Try, for example, to reconcile the widely diverging opinions I recorded during my field research between 1987 and 1989:

Zouk is a sentimental story. It's also a music for unwinding. It's a modern sound. Zouk is our generation [ages 18 to 25$]$ : it's us. ( ${ }^{*}$ Guadeloupe, June $1988)^{12}$

Zouk allows us to let off steam but brings no relief. It leaves people with a feeling of aggressivity and tension, which destroys the possibility of a cathartic effect. (*Martinique, May 1987)

Zouk is synonymous with relaxation, with letting go. The positive aspects of zouk are that it's sung in Creole, with lyrics in which there are no obscenities, no contempt toward women. In Kassav's lyrics, for example, there's just the right balance; they are neither moralizing nor simplistic. (*Guadeloupe, August 1988)

Zouk can alienate society. The themes are the same from one song to another. The rhythm and the lyrics are monotonous outpourings. The lyrics

11 For a useful comparison between a local scene and a musical community, see Will Straw, "Systems of Articulation, Logics of Change: Communities and Scenes in Popular Music," Cultural Studies 5, no. 3 (1991): 368-88.

12 An asterisk indicates that the quotation has been translated from French. 
have no force; they don't tackle the problems. There's no philosophy in them. (*Martinique, June 1988)

I like zouk because with it [since it's in Creole], people have become less reluctant [to speak it]. (St. Lucia, August 1987)

For me, zouk means freedom, joie de vivre. The rhythm is vital. The lyrics are secondary. (*Martinique, May 1987)

Zouk is a dance, it's engaging in physical contact with your partner. (*Martinique, July 1987)

Zouk is an assemblage of bits and pieces of traditional music. It's not a music played with real drums; it's only the product of the rhythm box. Zouk is a degenerate music. (*Guadeloupe, August 1987)

I like zouk because it has a great bass line, a good beat, and it's good for dancing. (St. Lucia, July 1987)

I like zouk because it has force [in it]. I have been preaching for ten years. Music creates unity much faster. Zouk is an acceptance of the difference. (*Martinique, June 1988)

Zouk is a social phenomenon. It is not popular for its musical content. Its harmony is often reduced to two chords. The melody is very repetitive. Even the brass section is played only in unison. Rhythmically, it's very simple. The words do not matter. It's a matter of sounds and phonetics to which people react. We like sounds and words for their phonetics. The rhythm is irresistible. The volume impels us to virtually get inside the music. (*Martinique, May 1987)

It is clear there is no consensus among zouk's fans and detractors about what the music has to say or how it speaks to them. Contradictions and diverging opinions are the norm. To try to analyze the meanings behind these statements and others like them, I tried to provide, in addition to an in-depth ethnography of the sound phenomenon, a detailed description of both the specific conditions in which zouk is experienced in each island and the various debates it has engendered. By specific conditions I mean the socio-political, economic, and cultural characteristics of each island. This information, I believed, could provide significant points of reference from which to discover and elucidate the 
relative meanings that zouk takes on for various peoples. And here I did what we normally do, that is, I tried to connect bits and pieces of information from many contexts, taking into account as many mediations as possible, to situate better the diverging opinions of those I interviewed.

This, however, did not contribute a great deal towards the democratization of voices in ethnographic text: my use of a profusion of quotations from various interviews or occasional dialogic passages did not leave much autonomy to the voices I quoted. As Clifford rightfully remarked: "Quotations are always staged by the quoter and tend to serve merely as examples or confirming testimonies."13 Given that it is never possible completely to remove the main ethnographer from an editorial position in producing a monograph that has been planned in the first place by that very ethnographer, my own objective for my monograph on zouk was to show the "process" by which researchers base their knowledge on other "oriented knowledges."

This meant that I needed to allow readers to hear (read) for themselves what my collaborators had to say, using the textual space they needed to make and explain their own statements, before I intervened with my own interpretation of what had been said. With this in mind, I asked three people to write essays to be included in my book. ${ }^{14}$

The three texts I gathered are rich ethnographies. They are also products of three different backgrounds, best evidenced in their distinct approaches: pedagogic, academic, and quasi-journalistic. The question here was not to determine whether the knowledge and construction of zouk were true or false, but rather to learn from which points of view each author addressed the genre in question and how each of their analyses informs the specific social, cultural, and musical practices that constitute zouk. For that reason, the traditional prerequisite of consulting a certain number of "informants" (a quantitative measurement) for the study to be considered credible was not a sine qua non here. ${ }^{15}$ Similarly, the question was not to find the "best" informant. What was needed was a point of view that was well articulated, explicit, and with a clear frame of reference,

13 Clifford, The Predicament of Culture, 50.

14 Jocelyne Guilbault, Zouk: World Music in the West Indies (Chicago: University of Chicago Press, 1993).

15 In his very insightful essay, "Ethnographic Authority" (The Predicament of Culture, 51), James Clifford questions the use of the term "informants," as for him the term itself reflects the power relation that has permeated much anthropological research in the past. His critical view is best summarized in his statement, "Anthropologists will increasingly have to share their texts, and sometimes their title pages, with those indigenous collaborators for whom the term "informants" is no longer adequate, if it ever was" (ibid.). 
that is, an influential discourse that has contributed to the social construction of zouk, as knowledge/power ${ }^{16}$ about and within zouk.

Two of the contributors are natives of the country in which the music originated (Guadeloupe and Dominica), and they both occupy an important place in their own milieus. They are recognized as sources of relevant, significant, and influential commentary on the local music scene, and their views are influential in the community at large.

Edouard Benoit introduced biguine, a music from Guadeloupe. Regarded as one of the best saxophonists in the country and as a veteran of the Antillean musical scene, he is currently the Adviser in Music Education for Guadeloupe. Over the past thirty years, Benoit has had a career as a jazz musician and also as leader of several well-known groups. After recording more than twenty-five albums, he continues to play professionally on a regular basis.

Gregory Rabess, who wrote on cadence-lypso, is a communication officer for the Small Projects Assistance Team (SPAT), a non-government organization supporting grassroots development in Dominica. Rabess has been deeply involved since the early seventies as a poet, writer, critic, and journalist, and, at one point during the boom years of cadence-lypso, as a musician. He was an active participant in the student and youth movements of the seventies and in the political movements of the mid-seventies and early eighties. His main interests are cultural and development projects.

Gage Averill is, to my knowledge, the first and only person to have done indepth research on Haitian compas direct/cadence rampa, an important element in establishing zouk's network. An American drummer who teaches ethnomusicology at Wesleyan University, he has received many commissions from Haitian associations in the United States, ranging from participating in radio programs to helping organize the Haitian festival in Miami. He has done studies on compas direct based on his fieldwork in Haiti (1987-89) and in Haitian communities in the United States. In addition to his "Haitian Fascination," a bimonthly column in The Beat magazine, he has published articles on Haitian music in scholarly journals.

\section{On Including, Mediating, and Interpreting Distinct Voices in Ethnographic Writing}

One could say that the texts produced were "framed" from the beginning, since they were conceived by the authors in an answer to my initial request. I was the

16 Michel Foucault, "Truth and Power," in Power/Knowledge: Selected Interviews and Other Writings, 1972-1977, by Michel Foucault, ed. Colin Gordon (New York: Pantheon Books, 1980), 109-33. 
one, after all, who determined the topic of the essays. After several interviews with zouk musicians, I learned that Guadeloupean biguine, Haitian compas direct, and Dominican cadence-lypso were the three musical genres that have had the most influence on zouk's evolution. At this point, I asked my three collaborators to introduce these musics and to comment on zouk's connections with them. This approach was conceived not just as a means of more easily gathering historical information on the evolution of Creole popular music. On a practical level, its importance lay in showing how these three musical genres have decisively oriented the way the populations of Guadeloupe, Haiti, and Dominica value zouk. On a theoretical level, this approach also aimed at demonstrating how each of these genres presents a notion of reality and how, in turn, each author draws on his grasp of that reality in interpreting the cultural and social history of the island and in formulating his own intellectual and aesthetic response to zouk. While it is true that the three essays were oriented by my initial questions, I believe nevertheless that they were written in terms decidedly different from those, to use Clifford's words, "of the arranging ethnographer."17 The three texts became three chapters in my book.

Including these texts did not, however, provide in and by itself an explanation of how the authors arrived at contradictory statements about the music, its history, and its musical properties. "Informants' [read "authors"'] intentions are overdetermined, their words politically and metaphorically complex." 18 What was needed was to locate the lines of argument, or frameworks, at the foundation of each paper and to see how these produce and organize the various properties attributed to zouk.

Following the three essays, I presented my own interpretation of what had been said. My aim was to illustrate how I was proceeding to abstract from the essays on biguine, compas direct, and cadence-lypso two types of knowledge: a knowledge about zouk, by highlighting its common and contrasting features with the other genres; and a knowledge from within, by presenting the ways in which zouk was perceived by each author. In other words, the presentation of my analysis of the essays would permit a description of the particular properties that link zouk to the three genres discussed as well as to those that are used to define it, and to see through which elements the family resemblance, and thus the network among these genres, had been established.

I presented at first the similar points of view that emerged. All three authors, for instance, agreed that zouk follows the pattern of inter-island cross-fertilization and hence is a musical synthesis of several popular and traditional musics of the Creole-speaking islands. They all saw zouk as a symbol of identity and 
nationalism and, because of its use of Creole lyrics, a force for unity among Creole speakers from the various islands. Each author acknowledged that zouk has expanded the Creole market and, by so doing, has made Creole music recognized internationally.

As important as it was to recognize the similarities in the three accounts, it was equally important to note the striking divergences. For example, depending on the country and the musical genre presented, zouk was defined as the offspring of compas direct, of biguine, or of cadence-lypso; it was claimed as "our" music in Haiti, Guadeloupe, and Dominica.

In an attempt to explain how the authors arrived at such contradictory statements (this is only one example, but there were many other stunning contradictory statements concerning the music, the reasons of its success, its musical properties, etc.), I presented what I saw as the organizing key elements of each essay in order to appreciate the viewpoints from which zouk was conceived, perceived, and evaluated as well as the relative weight given to some of its characteristics. This was a particularly sensitive interpretive moment where the reader could see how I interpreted each account and could decide whether to agree or disagree with my own assessment, having already read the essays in the preceding chapters. (For further information on my reading of the key arguments of each author, see Appendix 1.)

From the presentation of the contrasting frameworks, I was able to show how the three authors offered correspondingly very different interpretations of how zouk is perceived and received in their respective Creole-speaking islands. I was able to explain, for example, why in Averill's paper zouk is said to have caused resentment, in spite of its tremendous success in Haiti; or why, in one case, zouk musicians are declared to be first-rate whereas, in another case, they are described as inexperienced and lacking basic skills.

One interesting outcome of the reconstruction of each author's arguments which was primarily aimed at understanding their contradictory statements about zouk - was that it led me to question whether some of their apparently similar viewpoints had the same meanings and the same weight. For example, although they all agreed that zouk's success is linked to the market economy, it appeared that they did not refer to the same economic "causes." In the same way, although all three associated zouk's success with political events, the events selected by each author varied depending on what was believed to be at the root of his chosen music's decline-a decline that itself was viewed as one of the main reasons for zouk's success. Still in the same vein, although each author acknowledged zouk's tremendous impact, their comments followed three fundamentally different arguments (these are presented in Appendix 2, under the headings "decline," "success," and "impact" in the Historical and Socio-political Forces section). 


\section{Conclusions}

Including the essays by Benoit, Averill, and Rabess in my book offered many advantages. The three differing views on zouk showed in an irrevocable way that musical phenomena, and mass-distributed music in particular, cannot be defined in one way only. These essays revealed not only the remarkable number and kinds of elements that are at play, but also the contradictions that are integral parts of this music.

In light of these accounts, it was also possible to attempt a more detailed description of the network of compas direct, biguine, cadence-lypso, and zouk. The essays helped furthermore to confirm my initial hypothesis that this network operates on far more levels than that of sound alone. In addition, it features such diverse elements as social code, structure, and copyright laws, presenting them as all components of these musics, and thus of the cultures and practices of which zouk is tributary.

See, for example, Appendix 2, which highlights some of the features used by the three authors to describe biguine, compas, cadence-lypso, and zouk. (The letters B, A, and R under zouk attribute each statement to Benoit, Averill, or Rabess.) Note that the headings in the appendix have a descriptive rather than an analytical status, and are used only to organize the elements in a more readable fashion.

Appendix 2 illustrates, as was noted earlier, that some of the elements in the essays emerge as points of convergence, whereas others appear fully contradictory in ways that are not always obvious (for example, the acknowledged musicianship versus the so-called lack of it among zouk players). One possible conclusion that could be deduced from these "meeting" points, whether converging or diverging, was that they could be considered representative of some of the most significant influences on the perception and evaluation of zouk in the region or seen as representative of the focal elements in the ensemble of relations that link zouk with the three other genres.

Appendix 3 lists some of the focal elements that oriented the description of zouk's characteristics in the three essays. Taken as a whole, these elements are related to one another by links unique to the musical field encompassing zouk, biguine, compas direct, and cadence-lypso. This appendix defines the diverse kinds of links (linguistic, political, economic, historical, musical, racial, geographic, contextual) that characterize this historically and socially located musical field. In doing so, it illustrates the many ways in which zouk establishes a family resemblance with the three other genres. The elements in the essays considered central to the definition of zouk and the various configurations they form among themselves would, in fact, be different if zouk were placed within 
other musical fields of which it is also a musical part (for example, within the popular music of the English-speaking Caribbean), in the same way that it would also be different in a musical field of another time span, such as the eighties.

Including the essays by three different authors, followed by my analysis of these essays, while it suggests an alternate textual strategy of representing the Other in ethnographic writing, has not been an attempt to challenge the executive, editorial position of the ethnographer. Rather, it represents an attempt to make more visible the process by which researchers develop their knowledge on other "oriented knowledges" and how, in a multisubjective activity - from their selection of the terms of analysis, their limited experience, to their political, institutional, and personal motivations - they construct their own interpretation of a phenomenon.

\section{Appendix 1}

After the oral presentation of this paper at the annual meeting of the Society for Ethnomusicology at Seattle, Washington, October 1992, it was recommended that I introduce in my presentation what I saw as the organizing key elements of each essay to which I was referring, so that the audience could have an idea of how the three authors' viewpoints differ. As the main point of my paper is to show how readers can make sense of and put in perspective a researcher's interpretation by comparing the researcher's interpretation with their own reading, I would like to urge the present reader to do just that and to read the three articles included in Part II $^{19}$ after this brief summary of my own account of how zouk is constructed in each case.

For Benoit, zouk is an offspring of biguine through rhythmic elements in the percussion section and, at the same time, an extension of the music of the sixties and seventies (Haitian compas direct and cadence rampa followed by Dominican cadence-lypso) in most respects, including not only some aspects of the sound, but also the mode of transmission and apprenticeship, the social code of behavior, the selected social groups and the particular generation of people the music attracts, the venues where it is performed, and so forth. By comparing the musical scene of the forties with that of the sixties, and by extension, that of the eighties associated with some of the social and musical characteristics of zouk, Benoit constructs and opposes the world of biguine to that of zouk. While he recognizes zouk's impact by portraying it as the source of Guadeloupe's success in having transformed its popular music and having reached the international 
market, he makes it clear that he also holds zouk partly responsible for biguine's decline. He sees zouk as the epitome of all the characteristics associated with the musics from the 1960s onwards, which he set in opposition to biguine's own characteristics. In this light, zouk's impact is equivalent, according to Benoit, to a "turbulence musicale."

Averill introduces zouk as he did compas, defining it as the result of supranational processes of musical exchange and syncretism. In the same way that compas is the haitianizing of Dominican merengue (from the Dominican Republic), zouk is the antilleanizing of Haitian compas. Even though zouk exhibits characteristics of its own, Averill equates the Antillean music with compas because it shares the same swaying groove. He links its present characteristics with the increasing quality of the music produced by Dominicans, Guadeloupeans, and Martinicans during the late seventies: their stylistic innovations, their new arrangements, and their use of new technology - in short, the consolidation of an earlier trend.

While, according to Averill, Haitians love zouk, they also resent it: "Many musicians [feel] that they [have made] a mat on which someone else is sleeping;" that is, not only do Haitians consider zouk as compas in disguise, but they also feel they have been more or less ripped off by having lost control over their own product. Since, the argument goes, it is Haitian musicians who taught Antilleans how to play compas and it is Haitian musicians who are at the origin of zouk's rhythm, they should be given some credit and also benefit from the rewards that zouk enjoys today.

Rabess sees zouk as following the natural process of music evolution, a cultural process and product typical of the traditional Caribbean mode of fusion. In his view, it is connected to Africa via cadence-lypso and earlier versions of Creole music. Zouk is seen as the prolongation of Dominicans' own music (cadence-lypso) in its role as the latest-born in Creole music history. Because Rabess regards zouk as the consolidation of a trend that was emerging in the heyday of cadence-lypso, he identifies many of its musical elements as direct descendants of the last experiments of cadence-lypso. For him, zouk is welcome because it is said to have saved the country from being "taken over" by reggae and calypso and to have reinforced the use of Creole (since zouk is sung in Creole) and the Creoleness of the people in Dominica - which, according to the author, is considered the root of Dominican identity. 
Appendix 2

\begin{tabular}{|c|c|c|c|c|}
\hline $\begin{array}{l}\text { Biguine } \\
\text { Benoit }\end{array}$ & $\begin{array}{l}\text { Compas } \\
\text { Averill }\end{array}$ & $\begin{array}{l}\text { Cadence-lypso } \\
\text { Rabess }\end{array}$ & \multicolumn{2}{|c|}{ Zouk } \\
\hline \multicolumn{5}{|c|}{ Language } \\
\hline - Croole & - Creole & - Creole & & - Creole \\
\hline \multicolumn{5}{|c|}{ Choreography } \\
\hline $\begin{array}{l}\text { - description that relates in many } \\
\text { ways to tat kole, danis kole, and } \\
\text { kole stre }\end{array}$ & $\begin{array}{l}\text { - lut kolle } \\
\text { - about celebration and courtship }\end{array}$ & $\begin{array}{l}\text { - danat kolte } \\
\text { - about celebration and courtship }\end{array}$ & R & $\begin{array}{l}\text { - kole sere } \\
\text { - about celebration and courtship }\end{array}$ \\
\hline \multicolumn{5}{|c|}{ Historical and socio-political forces } \\
\hline $\begin{array}{l}\text { - performed at school parties, } \\
\text { communal fres, privale } \\
\text { celcbrations, and at balls restricted } \\
\text { to certain people (by invitation only) }\end{array}$ & & & B & $\begin{array}{l}\text { - offspring of biguine } \\
\text { - a disguised form of compas } \\
\text { - consolidation of a trend emerging in } \\
\text { the heyday of cadence-lypso } \\
\text { - more accessible to the public }\end{array}$ \\
\hline $\begin{array}{l}\text { - no youths, occasionally girls with } \\
\text { parents (i.e., special code of } \\
\text { behavior) }\end{array}$ & & & $B$ & $\begin{array}{l}\text { - emancipation of young girls and } \\
\text { greater freedom of youth in general }\end{array}$ \\
\hline - "formal" dress code & $\begin{array}{l}\text { - change of dress code (more } \\
\text { casual) }\end{array}$ & - change of dress code (more casual) & |B & - change of dress code (more casual) \\
\hline
\end{tabular}




\begin{tabular}{|c|c|c|c|c|}
\hline $\begin{array}{l}\text { Biguine } \\
\text { Benoit }\end{array}$ & $\begin{array}{l}\text { Compas } \\
\text { Averill }\end{array}$ & $\begin{array}{l}\text { Cadence-lypso } \\
\text { Rabess }\end{array}$ & Zouk & \\
\hline \multicolumn{5}{|c|}{ Historical and socio-political forces (cont'd.) } \\
\hline & $\begin{array}{l}\text { - Impact: symbolizes } \\
\text { Afro-Caribbean identity }\end{array}$ & $\begin{array}{l}\text { - Impact: helped Martinique and } \\
\text { Guadeloupe in their assertion of } \\
\text { cultural and national identity } \\
\text { - reinforced Creoleness } \\
\text { - helped change aluitudes loward } \\
\text { injustice and repressive laws } \\
\text { - revolutionized Creole music, Creole } \\
\text { culture, and Creole language } \\
\text { - laid a solid foundation for the } \\
\text { development of zouk }\end{array}$ & $\begin{array}{l}\text { A } \\
\text { A } \\
\text { A } \\
\text { B A A }\end{array}$ & $\begin{array}{l}\text { - Impact: resurgence of ethnic identity } \\
\text { and cultural nationalism } \\
\text { - reinforced Creoleness, the identity of } \\
\text { the people } \\
\text { - prevents the dominance of } \\
\text { non-Croole musics in Dominica } \\
\text { - a catalyst, call for action } \\
\text { - transforms popular music in } \\
\text { Guadeloupc; responsible for biguine's } \\
\text { decline } \\
\text { - deghettoizes Creole music }\end{array}$ \\
\hline $\begin{array}{l}\text { - features Guadeloupcan cultural } \\
\text { and ethnic identity }\end{array}$ & $\begin{array}{l}\text { associated with political situation } \\
\text { in Haiti (French names for groups, } \\
\text { Creolc lyrics) } \\
\text { - Haitianizing of the Dominican } \\
\text { merengue } \\
\text { - associated with two labels } \\
\text { (compas direct and cadence-rampa), } \\
\text { with two cultural heros (Nemours } \\
\text { Jcan-Baptiste and Weber Sicot), } \\
\text { with competition betwoen two } \\
\text { musicians and leading groups }\end{array}$ & $\begin{array}{l}\text { - contemporary expression of } \\
\text { Dominican folk music (traditional } \\
\text { forms of music, jing-ping, translated to } \\
\text { modern instruments) } \\
\text { - connected to a particular group: } \\
\text { Exilc One }\end{array}$ & B & $\begin{array}{l}\text { - linked with individual personality and } \\
\text { national identity of Guadcloupe }\end{array}$ \\
\hline $\begin{array}{l}\text { - mixture of ethnic groups and } \\
\text { civilizations }\end{array}$ & - inter-island cross-fertilization & - mixturc; cross-fertilization & BAR & $\begin{array}{l}\text { - mixture of ethnic groups and } \\
\text { civilizations }\end{array}$ \\
\hline
\end{tabular}


Appendix 2 (Concluded)

\begin{tabular}{|c|c|c|c|c|}
\hline \multicolumn{5}{|c|}{ Historical and socio-political forces (cont'd.) } \\
\hline $\begin{array}{l}\text { - linked with specific institutions } \\
\text { (philharmonic orchestra, casinos, } \\
\text { nightclubs) }\end{array}$ & $\begin{array}{l}\text { - associated with institutions that in } \\
\text { turn are associated with teenagers } \\
\text { (movie theaters, volleyball games, } \\
\text { and school kemis) } \\
\text { - nightclubs, salons }\end{array}$ & & & \\
\hline $\begin{array}{l}\text { - declline: external musical } \\
\text { infleences often negative, inveding, } \\
\text { dominating, and creating a musical } \\
\text { turbulence; lechnology can be } \\
\text { limiting (e.g., recording equipment) }\end{array}$ & $\begin{array}{l}\text { - decllne: increasing quality of } \\
\text { music and stylistic innovation by } \\
\text { Dominicans, Guadeloupeans, and } \\
\text { Martinicans (new arrangements and } \\
\text { new use of tochnology); rise of } \\
\text { American dollars (higher cost of } \\
\text { Haitian records); holdover of the } \\
\text { tainted cultural legacy of Papa and } \\
\text { Baby Doc; divided by competition } \\
\text { for the limited Creole market; } \\
\text { protective measures of Martinique } \\
\text { and Guadcloupe }\end{array}$ & $\begin{array}{l}\text { - decline: lack of financial support for } \\
\text { bands; refusal of Dominicans to be } \\
\text { exploited any longer }\end{array}$ & BAR & - success is fragilc, ephemeral \\
\hline $\begin{array}{l}\text { - success: promoted by Syndicat } \\
\text { d'Institution de la Guadcloupe }\end{array}$ & $\begin{array}{l}\text { - success: encouraged by } \\
\text { Jean-Claude Duvalier's new } \\
\text { liberalizing policy; his } \\
\text { encouragement of mini-djaz; } \\
\text { massive injection of new moncy at } \\
\text { the time }\end{array}$ & $\begin{array}{l}\text { - success: corresponds to: turning } \\
\text { point in Dominica's social and political } \\
\text { identity; the concommitant Black } \\
\text { Power movements (campaigns on the } \\
\text { issues of race, class, identity, and } \\
\text { oppression); spread of Rastafarianism; } \\
\text { the new repressive laws during the } \\
1970 \text { s rebellion of youth at the dawn } \\
\text { of Dominica's independence; migration } \\
\text { of musicians to Guadeloupe }\end{array}$ & $\begin{array}{l}\text { R } \\
\text { A } \\
\text { B } \\
\text { A } \\
\text { A }\end{array}$ & $\begin{array}{l}\text { - success: corresponds to the vacuum } \\
\text { in the output and creativity of } \\
\text { Dominican bands } \\
\text { - corresponds to revolutionary period } \\
\text { surrounding the ouster of the Duvalier } \\
\text { family from presidency } \\
\text { - rise against Haitian imperialism in } \\
\text { the French Antilles } \\
\text { - copyright protection, use of new } \\
\text { technology; boom in the rocording } \\
\text { industry at the advent of radios libres, } \\
\text { greater public access to music, and } \\
\text { thus to zouk } \\
\text { - corresponds to protective measures of } \\
\text { French departments } \\
\text { - casy access to resources }\end{array}$ \\
\hline
\end{tabular}




\section{Appendix 3}

\begin{tabular}{|c|c|c|}
\hline Focal Elements & Links & Related Focal Elements \\
\hline \multirow{5}{*}{ Process of deghettoization } & $\begin{array}{l}\text { in relation to the political situation of } \\
\text { the French departments in the Antilles }\end{array}$ & Creole \\
\hline & economic success & international market \\
\hline & $\begin{array}{l}\text { - new confidence of local people about } \\
\text { their own music (e.g., sponsorship) } \\
\text { - expansion of market network }\end{array}$ & local industries \\
\hline & scceptance of hybrid identity & $\begin{array}{l}\text { general impact on local practices and } \\
\text { local industries }\end{array}$ \\
\hline & fight against racism & ethnic and cultural identity \\
\hline \multirow{2}{*}{ Zouk's "ephemeral" success } & $\begin{array}{l}\text { context of insularity and smallness of } \\
\text { the islands (need for changes) }\end{array}$ & perpetual transformation \\
\hline & $\begin{array}{l}\text { the constant challenge of a popular } \\
\text { music to remain "popular" }\end{array}$ & local and international industries \\
\hline \multirow[t]{4}{*}{ Economic success } & $\begin{array}{l}\text { - the regional enforcement of } \\
\text { SACEM* in the } 1980 \text { s } \\
\text { - new markets } \\
\text { - new means of distribution } \\
\text { - the advent of sponsorship in the } \\
\text { region }\end{array}$ & $\begin{array}{l}\text { impact on local music industries and } \\
\text { local practices }\end{array}$ \\
\hline & deghettoization of Creole music & international market \\
\hline & greater wutonomy & identity \\
\hline & $\begin{array}{l}\text { now includes new entrepreneurship in } \\
\text { the Antilles }\end{array}$ & musical training \\
\hline \multirow[b]{2}{*}{ Expanded international market } & effects of the mass-media of the 1980 s & $\begin{array}{l}\text { - foreign influences } \\
\text { - deghettoization }\end{array}$ \\
\hline & $\begin{array}{l}\text { new implicit requirements of popular } \\
\text { music of the 1980s }\end{array}$ & $\begin{array}{l}\text { - musical training } \\
\text { - musical characteristics (specifically in } \\
\text { regard to certain sound effects and } \\
\text { electronic instruments) }\end{array}$ \\
\hline \multirow{7}{*}{ Musical characteristics } & $\begin{array}{l}\text { - musical traditions of the region } \\
\text { - geographic and linguistic links } \\
\end{array}$ & inter-island cross-fertilization \\
\hline & $\begin{array}{l}\text { - reliance on technology } \\
\text { - pressures of international music }\end{array}$ & international market \\
\hline & Creole traditions & identity \\
\hline & $\begin{array}{l}\text { - migration to neighboring islands, } \\
\text { France, and Africa } \\
\text { - Creole traditions } \\
\end{array}$ & musical training \\
\hline & family resemblence & offspring \\
\hline & $\begin{array}{l}\text { - migration of musicians } \\
\text { - soundscape through radio and } \\
\text { television broadcast in the region }\end{array}$ & foreign influences \\
\hline & $\begin{array}{l}\text { competing musics and other social. } \\
\text { political, and economic forces in the } \\
\text { islands and international markets }\end{array}$ & ephemeral success \\
\hline \multirow{3}{*}{ Zouk as an offspring } & family resemblance & perpetual transformation \\
\hline & Africen connection & Creole traditions \\
\hline & $\begin{array}{l}\text { newest Creole popular music in } \\
\text { relation to chronology }\end{array}$ & inter-island cross-fertilization \\
\hline
\end{tabular}

* Socieac des Auteurs, Compositeurs, et Éditeurs de Musique 


\begin{abstract}
This paper addresses the researcher's double challenge: to acknowledge and situate contrasting experiences of the same phenomenon and yet to integrate them into a personal rendition of that phenomenon. An examination of the various strategies employed in ethnographic writing, from the copious use of quotations to dialogical or polyphonic writing, shows how contradictory viewpoints have been given more attention in ethnographic literature, as the politics of representation have developed into an important debate in the social sciences. While these various approaches have undeniably allowed more voices to be heard, they have nevertheless left unanswered the problem of interpretation in the case of contested appropriations or contradictory versions of the same phenomenon. The simple fact of integrating various voices in an ethnography does not indeed constitute in an by itself an explanation of what is being said and why.

This paper examines possible uses and treatments of diverging voices in ethnographic writing. By way of illustration, I emphasize the great complexity of the responses and interpretations generated by zouk, a mass-distributed popular music from the West Indies, by presenting contrasting voices and viewpoints from the islands of Guadeloupe, Martinique, Domenica, and Haiti. By doing so, I show, on the one hand, how each viewpoint can provide distinct types of knowledge. On the other hand, I argue that while there can be no analysis which can provide final answers to the questions raised by controversial phenomenon such as zouk, not all the points of view should be accorded the same importance.
\end{abstract}

